Society in Prehistory 
Also by the same author

From the Caves to Capital

The Making of Modern Japan: A Reader 


\title{
Society in Prehistory
}

The Origins of Human Culture

\author{
TIM MEGARRY
}

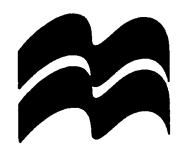




\section{(C) Tim Megarry 1995}

All rights reserved. No reproduction, copy or transmission of this publication may be made without written permission.

No paragraph of this publication may be reproduced, copied or transmitted save with written permission or in accordance with the provisions of the Copyright, Designs and Patents Act 1988, or under the terms of any licence permitting limited copying issued by the Copyright Licensing Agency, 90 Tottenham Court Road, London W1P 9HE.

Any person who does any unauthorised act in relation to this publication may be liable to criminal prosecution and civil claims for damages.

First published 1995 by

MACMILLAN PRESS LTD

Houndmills, Basingstoke, Hampshire RG21 2XS

and London

Companies and representatives

throughout the world

ISBN 978-0-333-31118-9

ISBN 978-1-349-24248-1 (eBook)

DOI 10.1007/978-1-349-24248-1

A catalogue record for this book is available from the British Library.

$\begin{array}{rrrrrrrrrr}10 & 9 & 8 & 7 & 6 & 5 & 4 & 3 & 2 & 1\end{array}$

$\begin{array}{llllllllll}04 & 03 & 02 & 01 & 00 & 99 & 98 & 97 & 96 & 95\end{array}$

Copy-edited and typeset by Povey-Edmondson Okehampton and Rochdale, England 


$$
\begin{gathered}
\text { For } \\
\text { Katy and Matty } \\
\text { and for my father } \\
\text { Bill Megarry } \\
\text { who first introduced me to human evolution }
\end{gathered}
$$




\section{Contents}

List of Illustrations viii

Acknowledgements ix

Introduction: Prehistory and Society 1

1 Evolution and Human Society 18

2 Culture and Evolution $\quad 45$

3 Biology and Culture 64

4 Primate Societies $\quad 91$

5 The First Hominids 113

6 Tools and Culture 154

7 Tools, Brains and Behaviour 182

8 A Foraging Economy 207

9 Man the Hunter? 226

10 Modern Humans and Human Behaviour 266

11 Sex and the Division of Labour 291

12 Sexuality and Social Life 312

$\begin{array}{ll}\text { Glossary } & 347\end{array}$

Further Reading $\quad 354$

Bibliography 356

Index $\quad 387$ 


\section{List of Illustrations}

\section{FIGURES}

1.1 A model of the origin of species

1.2 Evolutionary adjustment by natural selection 38

4.1 Taxonomic and phylogenetic relationships of living hominoids

5.1 Diagrammatic representation of the reciprocal feedback process involved in hominid evolution

6.1 Palaeolithic stone tools (see with Table 6.1)

6.2 A representation of relationships in the human fossil record

7.1 The procedural templates involved in making Oldowan and Acheulian tools

7.2 A possible configuration of the social behaviour of tool-making hominids two million years ago

\section{TABLES}

1.1 The geological timescale of human evolution

1.2 Timescale for human evolution and cultural development

6.1 Palaeolithic tool manufacture

7.1 Brain volumes of hominid species 


\section{Acknowledgements}

Special thanks are owed to Paul Hirst, Stephan Feuchtwang and Henrietta Megarry for their help and encouragement over many years and to Bernard Campbell for encouragement and advice. I must also thank Janet and Richard Briffett, Brigitte Flock, Imogen Forster, George Hallam, John Hood-Williams, Mike Kelly, Joanne Robertson and Hazel Shave.

Acknowledgements and thanks are also due to authors and publishers for allowing the use of copyright material as follows:

Barbara Isaac, Peter Andrews and Garland Publications, Bernard Campbell and Aldine de Gruyter, John Gowlett and Academic Press, and British Museum Publications. 